\title{
Rethinking mobility in criminology: beyond horizontal mobilities of prisoner transportation
}

In recent years, mobilities have become a central concern for scholars seeking to understand a world that is ever on the move (see Adey, 2009; Cresswell, 2010; Merriman, 2013; Sheller and Urry, 2006; Urry, 2007). Exploring mobile lives in the past has been a firm part of this effort and has helped to make sense of both historical events and the formation of mobility norms in the present (Anim-Addo, 2014; Leary, 2014; Merriman, 2007). Following Moran et al. (2012) - in a seminal paper that urges carceral scholars to embrace mobility - we likewise contend that there is a need to take seriously movement in carceral settings. Indeed, in spite of common assumptions relating to the 'fixity' of carceral experience, '[m]obility is ... a constant practical concern in the management of penal systems' (Moran et al., 2012: 449).

Accordingly, whilst contributions have unhinged carceral spaces from sedentarist ontologies that conceptualise spaces of detention, imprisonment and captivity as ones of stability and fixity, (see Gill, 2009; Moran et al., 2012; Pickering and Weber, 2006), we argue that where motion has been considered, it has been through a predominantly linear, flat approach. In contemporary carceral studies, to move is to journey from point to point, charting a geometric and horizontal trajectory across space. Even where movement is circular, it follows a line - a loop - that connects start points to end points (see Ingold, 2007). Yet as scholars have argued, mobility is the politics of motion in the process of moving. Accordingly, mobility is not the abstract macro- 
movement along a path or line: it is the minute, intimate, embodied, power-filled ways and methods of moving within the path or along the line. If we are to move (literally) beyond thinking of carceral movements as 'travels' between fixed nodes to a more probing understanding of how, why, whom, by what means, and under what conditions subjects, objects, ideas and elements move - then the literature still has some way to go. With mobility studies exploring the ways in which motion is never straight-forward occurring forwards and backwards; horizontally and vertically; as well as under and over (see Adey, 2010) - we use the example of the convict ship to attend to how a specifically vertical approach may reconfigure understandings of carceral mobility, adding 'height and depth' (Elden, 2013: 35) to discussions. This leads to a greater comprehension of the politics of how, why and where incarcerated individuals move (or are unable to move) within regimes and volumes of disciplinary control, as well as through practices of resistance enacted and performed through the architectural shape of the prison. Although accounts of convicts ships are plentiful in academic and popular literature (see Anderson, 2000; Bateson, 2004; Campbell, 1994; Vaver, 2011); little attention has been paid to prison vessels in respect of mobility explicitly.

The convict ship was a space most obviously mobile through the journey from Britain to the Colonies, yet numerous other mobilities were also present inside the vessel as the crew and convicts engaged in everyday life on board: exercising on deck; the rhythmic washing of clothes against a board; and the repetition of picking oakum, amongst others. On board, mobilities were complex, multi-directional, horizontal and vertical; driven by social forces and frictions, alongside the dynamics driving the 
undulation of the ship at sea (the waves, currents, wind and so on) (see Peters and Turner, 2015). Therefore, the convict ship demonstrates how prisoners moved in varied ways, not only through regimes of mass mobility facilitated by technologies of transportation. Mobility was a constant in the embodied lives of those incarcerated. Far from being static within the confines of prison space, prisoners - on a micro, intimate scale - still moved; be it disciplined, coerced or otherwise (see Moran et al., 2012; Peters and Turner, 2015; Pickering 2014). Notably though, they moved within the volumes of space available, and it was through this volume that power was exercised (see Weizman, 2003).

In what remains, we split the paper into three parts. We begin by outlining in greater detail the mobilities paradigm and its adoption in carceral studies, particularly through the lens of geography. We then observe the necessity for exploring vertical motion in order to take seriously how disciplinary control and resistant practices are realised through the volume of penal settings. Finally, to exemplify how such an approach can deepen our understandings of the practical workings of discipline and control in the contemporary penal landscape, we then turn to the convict ship as a case study for drawing out the multi-directional mobilities of incarceration.

\section{Mobility studies and carceral space}

In contemporary studies of carceral settings, geographic interventions have sought to explore the multiple spaces, times and experiences encapsulated before, during and after detention, confinement, imprisonment and captivity (see Conlon, 2011; Loyd et al., 
2012; Martin and Mitchelson, 2009; Moran, 2015; Pallot, 2005, 2007; Turner, 2012, 2013a, 2013b). Whilst mobility features in this pivotal work, approaches are centred on the predominantly fixed geographies of the prison and limited mobility (or immobility) of subjects therein. This is due to the common assumption that incarcerated experience is anything but mobile (Moran et al., 2012: 449). Indeed, as Ong et al. write 'while studies of prisoner, passenger and migrant subjects examine the intricate spatialities of ... control, they tend to focus on ... the more rooted/immobile disciplinary and punitive nature of prison spaces and carceral geographies' (2014: 5). Carceral experience is often said to be one of fixity - movement of the subject is limited within specific parameters or boundaries - with liberty and agency greatly reduced (Moran et al., 2012: 449). Indeed, 'prisons may seem to be the epitome of immobility, with inmates incarcerated within a static physical space of detention' and as such, carceral scholarship is particularly 'at risk of neglecting mobility' (Moran et al., 2012: 449). This sedentarist ontology has resulted in the manifold mobilities that permeate prison life and reality being overlooked.

Accordingly, of late, carceral scholars have argued that mobility may well be a useful framework for understanding experiences of incarceration. Mobility, as Moran et al. (2012: 449) note, is ever present in carceral settings in the movement to, from and between prisons. Broadly defined, mobility unhinges a way of knowing that 'assumes a stable point of view, a world of places and boundaries and territories rooted in time and bounded in space' (Cresswell and Merriman, 2012: 4) and is instead alerted to a vision of the world built on fluidity, flows and connections. Mobilities are attuned to the 
messy, complex, contradictory, unmappable realities of how, where, why and by what means people move or are unable to move. Such studies are pertinent in carceral settings, where scholars increasingly recognise how movement (or a lack of movement) underscores experience in and between prisons, detention centres, custody units and so on (Gill, 2009; Moran et al., 2012). Indeed, on closer inspection mobilities are evident in the very act of incarceration as subjects are moved or removed from wider society, crossing a border from the 'outside' to the 'inside' (Turner, 2014, 2016). Moreover, as Moran et al. (2012) demonstrate in their study of train transport in the context of the Russian etap, there are a host of mobilities present in the movement of individuals to/from prisons and between prisons that are often sorely neglected. Furthermore, once inside the prison, a range of (im)mobilities are evident from the macro scale of movement or restriction of movements around the prison space (between the cell, the canteen, the visiting room); and at the micro-scale of the individual body through disciplined movement, requiring subjects to walk, work, rest and play in ways that limit motion to adhere to particular rules and regimes. Additionally, as Turner (2013b) identifies, prison space is far more fluid than we might imagine: prisoners escape, illicit objects flow into and out of jails over walls, under fences and via transportation on/in persons (see also Turner, 2016). Subsequently, there has been a growth in research that attempts to interrogate mobility in relation to the processes and experiences of incarceration - yet this has not been fully exploited.

In previous work we have contributed to the agenda set by Moran et al. (2012), by arguing that carceral mobility does not simply entail those coerced or disciplined 
movements wholesale from location to location. Carceral mobility involves the coerced, disciplined and also emancipatory, minute, temporal, partial and laborious motions that are part and parcel of what it is to be incarcerated (see Peters and Turner, 2015). Expanding from this argument, in this paper we contend that not only do current engagements with mobility in carceral settings privilege an understanding that omits a more nuanced discussion of micro-mobilities and embodied motions, but it also crucially - produces a largely geometric, flat or horizontal vision of movement from point to point. This has resulted in a limited consideration of the nuanced range of mobilities - forwards, backwards, up and down - that shape and define incarcerated life. Studies of carceral mobility, we argue, have been without height or depth. They have lacked volume (Elden, 2013).

Our argument for attention towards the vertical, or voluminous dimensions of carceral life, is inspired - in part - by the work on carceral circuitry (see, for example, Clear et al. 2003). Considering the challenges facing urban localities in the $21^{\text {st }}$ century, Clear and colleagues posit that incarceration is a key factor driving social disorganisation, alongside instances of crime, isolation, family breakdown and high unemployment (2003: 34). Indeed, it is the relationship between social (dis)organisation and incarceration that amplifies the challenging social conditions faced by neighbourhoods, because of a continual removal and then return of individuals to/from urban areas. As Clear et al. note 'whatever the positive effects of the removal of prisoners, the offenders eventually return and their return poses a set of problems at the neighbourhood level' (2003: 60). It is a circular loop of populations moving 'into and 
out of neighbourhoods' that creates an unstable and volatile environment, because of constant motion between inside and outside. On the one hand, the circuits Clear et al. (2003) describe, are linear. They conform to the flat approach towards mobilities that carceral studies have largely adopted. A circuit, though a loop, is no less a line. As Ingold thought-provokingly contends (see 2007), a line is not always straight. If you were to draw a loop on a sheet of paper, it is no less a line. It still has a beginning and an end. The end simply connects back to the beginning. It remains flat in its realisation.

Circuits, for Clear and colleagues, consist of neighbourhood removals and community reintegration- that shifts people in, and then out of prison, along a line that is merely looped - therefore always permitting a chance of return. That said, whilst the notion of a circuit supports the need for a more nuanced conceptualisation of carceral mobilities that attend to height and depth, it does move us in this direction. Indeed, as Clear et al. demonstrate, the circuits established between prison and society are not simply flat loops. Rather, there is a 'population churning' in socially disorganised neighbourhoods (Clear et al., 2003: 38). The notion of a 'churn' (see also Steinberg and Peters, 2015) alludes to an altogether more voluminous phenomenon - a motion that has ups and downs as well as backs and forths. As such, we contend that attending to vertical dimensions and movements, and in situ with the horizontal, may reveal a multiplicity of movement that is better able to help us understand carceral life: both the (im)mobile experiences of incarcerated subjects and the motionful regimes of governance that confine them. 


\section{Verticality and prison space}

Height and depth are vital to the operation of power in penal settings (see also Weizman, 2003). This becomes particularly apparent when we consider the multiple transactions and connections that occur across the prison boundary (Turner, 2016). Many examples include those relating to prison escapes or the presence of contraband. Jack Sheppard was a robber, burglar and thief, who was arrested and imprisoned five times in London in 1724. He escaped four times from his cell high above ground level by using bed-clothes knotted together. Other prisoners employed subterranean activities. In 1944, a 102-metre tunnel led Roger Bushell and 75 other successful escapees to freedom from the Stalag Luft III prison during World War Two. The story was made into the film The Great Escape. Other prisoners travelled upwards. Alfred George Hinds was convicted for a jewellery robbery and sentenced to 12 years imprisonment in 1953. He escaped from Nottingham Prison in 1955 over a 20-foot prison wall. Similarly, eight inmates escaped from the Curry County Adult Detention Centre in Clovis, New Mexico in 2008 by climbing pipes in a narrow space inside a wall and using homemade tools to cut a hole in the roof. Most spectacularly, in 1987, John Kendall and Sydney Draper escaped from HMP Gartree when a helicopter landed in the exercise yard. The notion of the aerial has also made an impact in the presence of contraband in prison spaces. Many items are simply thrown up and over prison walls and fences to be collected by those waiting on the other side, embracing the very threedimensional capacities of space for resistant practices. However, advances in technology have also witnessed some more inventive transgressions. In November 
2013, four people were arrested after a remote-controlled helicopter was allegedly used to fly tobacco into Calhoun State Prison, Georgia, USA. And in March 2014, a man was arrested for allegedly trying to smuggle drugs into an Australian prison using an unmanned drone.

Second, an attention to verticality can used to understand spatial movements within the prison itself. Whilst incarcerated, prisoners experience vertical movements dependent upon the regime of the prison and their individual categorisations. For example, in some prisons, inmates sleep in double or triple bunk beds. The hierarchical relationships and territorial contestations that this living situation manifests can have major implications for individuals' ability to afford themselves privacy and avoid confrontational circumstances (for an example of how dormitory situations are enacted as visual landscapes, see Van Hoven and Sibley, 2008). Additionally, prisoners may be located on specific 'landings' within the prison depending on their status according to the Incentives and Earned Privileges Scheme (IEP). Prisoners on enhanced status may occupy cells in higher tiers of the prison owing to their good behaviour. Access to these areas would be restricted for non-Enhanced prisoners, confining them to the lower levels of the wing. In some cases, sex offenders have been housed in the top levels of prison, ensuring that they will not interact with prisoners from the rest of the population due to the risk of potential aggravation by the nature of their crimes (Wener, 2012). Power in the prison then, is often expressed through the very volumes of space that are opened up vertically (see Weizman, 2003). 
Conversely, casting individuals downward has long been associated with the subjugation of wrong-doers. Dungeons, whilst often romantically represented in fairy tales, were symbolic of most medieval castles and were largely altogether less pleasant environments. The original Newgate Prison in London has often been called 'hell above ground'. Moreover, when Connecticut's first prison was built in an old copper mine, its living conditions were dismal because barely any sunlight made its way down the steep shafts. The cells were damp, mouldy, and claustrophobic. Most early-modern prisons also featured an oubliette (from French, literally 'forgotten place'). This deep hole, dug well below the prison floor had only one escape route - a trap door in the ceiling. Here, prisoners were often left to starve in the cold, damp darkness, squeezed into the tiny square of floor at the bottom of the shaft. In both these examples, confining prisoners to spaces below the earth without the comfort and warmth of natural light was a mark of domination over those individuals. As such, occasions where inmates were able to 'rise upward' through the prison architecture demonstrate deliberate acts of resistance. Rooftop protests have become a fierce symbol of defiance within the penal setting. In Britain, rooftop protests were significant in the Strangeways riots in 1990. Most recently, in 2013 six prisoners sat atop HMP Oakwood in Wolverhampton for six hours.

It is at this point that we draw upon our final example, that of the Panopticon. The Panopticon, designed by English philosopher and social theorist Jeremy Bentham in the late- $18^{\text {th }}$ century, consists typically of a circular structure with an inspection house tower at its centre, from which the managers or staff of the institution are able to watch or observe (-opticon) all (pan-) the inmates, who are stationed around 
the perimeter. Inmates would be unable to tell whether or not they were being watched. The rationale for the Panopticon was predicated on the ability of the prisoner to selfregulate their mobilities, believing themselves to be watched by all others imprisoned within the radial layout (See Bozovic, 1995). The Panopticon provides a useful example of how height and depth create radial expressions of power that rely crucially on vertical projections. The Panopticon prison design is predicated on the vertical omnipresence of the guard in the tower which then permits surveillance and self-regulation of the individual across the building. It therefore demonstrates how an understanding of movement in the prison must extend beyond the horizontal, because governance is not flat. It is operationalised through controlling mobilites within a volume of space.

In highlighting these examples, we demonstrate the significant relationship that exists between vertical movements (upwards and downwards), horizontal movements (across and through) and power (both hegemonic and resistant). We next turn to the example of the convict ship to provide a more nuanced understanding of how incarcerated individuals move (or are unable to move) within regimes of disciplinary control.

\section{The convict ship}

Transportation of individuals via ship can be first dated to 1584 when Richard Hakluyt (c. 1552-1616), a geographer, cleric and historian suggested using convicts as a free workforce in the American Colonies. By the late-16th century this process was institutionalised to a greater degree and by the late-18th century, as part of a growing 
call to civilise punishment in Britain, the shipping of convicts was a preferred sentence for many (Radzinowicz and Hood, 1986; Vaughan, 2000; Willis 2008). The Piracy Act 1717 established a seven-year penal transportation to North America as an alternative punishment for those convicted of lesser felonies. In addition, those with more serious sentences - such as the death penalty - could have this sentence translated to one of transportation via a Royal pardon. In this way, transportation became a much-used method for disposing of convicted people. Transportation of criminals to North America thrived from 1718 to 1776 . By $1775,50,000$ British convicts were transported to North America. When the 1776 American War of Independence prevented the continuation of this transportation, criminals were instead transported to the British Colonies in Australia and Van Diemen's Land (Tasmania) (The Howard League for Penal Reform, 2012). The years 1787-1868 witnessed the movement of 162,000 British and Irish convicts in 806 ships to these destinations (Brooke and Brandon, 2005: 13).

In order to make observations about vertical mobilities, and the politics embedded within the volume of space that was the convict ship, we draw on a variety of archival records, alongside published accounts of incarcerated life at sea. Primarily we draw on Admiralty records held at the National collection in Kew, focusing our attention on captain's diaries and the medical folios of surgeons (or doctors) on the ships dating from 1819-1857 (this marking a peak period of transportation to Australia and Tasmania). That said, our aim here is not to provide a neat, chronological historiography of the era of transportation. Rather, we take a thematic approach, piecing 
together various instances of mobile experience, shuttling back and forth (and up and down) throughout this wider period in penal history.

Moreover, whilst it might be possible to explore mobility in respect of any carceral setting such as a traditional landed prison, we contend that the convict ship permits us to explore the mobilities of carceral experience in exemplary ways. Most obviously, the convict ship is a prison that moves. Ships (of any kind) most noticeably move from port to port, across space (Hasty and Peters, 2013). Indeed, ships have been regarded, somewhat simply, as the facilitators of horizontally linking the spaces of capital accumulation - cities, towns and so on (Steinberg, 2001). Certainly the convict ship can be regarded in such as way. Firstly, such ships facilitated the A to B movement of all kinds of people - not merely convicts. The Almorah was employed in moving convicts from Ireland to New South Wales in June 1820. However, the ship also carried James Fitzpatrick, his wife, and two children. Similarly, when the guard (consisting of a lieutenant, sergeant, corporal and 28 privates) boarded the Albion on 10 May 1828, they were also joined by five wives and eight children. Three wives also joined their husbands aboard the Lady Ridley in 1821. Moreover, the embarking and disembarking of convicts in particular - the start and end of their linear journey - were points of celebration amongst the crew of ships, particularly surgeons, whereby the delivery of a healthy cargo of convicts represented a successful voyage (see for example the general remarks of Robert Espie, Surgeon aboard the Dorothy, 182011). Moreover convict ships were evidently involved in horizontal, lateral passages. The marking of equator crossings, for example, demonstrates the ways in which horizontal motion was 
recorded, and traditional practices related to this maritime rite were observed, by both convicts and crew. As William Hamilton noted,

The ship crossed the equator this forenoon. That event being expected, and the women ... having expressed a wish to witness the usual ceremony amongst seaman on such an occasion, which from their good behaviours I complied with. Soon after noonday the men who had not been so far before were initiated, the women joining in free sprinkling of water, with much good will and humour. (Diary of William Hamilton, Surgeon and Superintendent, Elizabeth, 1 September $1818^{2}$ )

Yet, ships are also mobile in a multitude of other ways. They move not on water (assuming water to be a surface or plane) but through it and in it. Water has volume (see Steinberg and Peters, 2015). Via this connection with the loose, molecular form of water, ships also move up, down; they list, they tilt, they rise, fall, drift and so on. Prison ships are no exception. Cases of bad weather, resulting in erratic movements and subsequent sea-sickness of incarcerated subjects, are rife in descriptions of life on board. Yet the convict ship is not merely a form of transportation between prisons, but is likewise a prison in and of itself. In this prison space - a space of apparent detention and confinement - incarcerated subjects inside the ship also move and these movements take a variety of forms and trajectories. However, these movements have vertical and horizontal limits, producing a contained volume of space for incarceration. The ship, 
therefore, allows us to move our attention to the ways in which carceral experience is generated through various dimensions - not simply the horizontal, but the vertical and also the myriad of angles, inclines and tilts that characterise movement which is not simply two-dimensional (see Elden, 2013). In what follows we trace a more nuanced picture of the mobilities interrogating the vertical qualities of carceral life so often overlooked in flat explorations of prisoner mobilities in order to begin our efforts towards opening attention to the complexity of space through which carceral life is lived.

\section{Vertical (im)mobilities on the convict ship}

What is striking about convict ship transportation, particularly in the era to which we refer, is the 'excellent care' received by convicts whilst on board and the 'high state of health' in which they arrived in the Colonies (Diary of Edward Foord Bromley, MD and Superintendent of Convicts, Lord Wellington, 1819³ , emphasis added). From 1801, convict transportation was subject to tighter regulation by the British Government in terms of provisions and medical support following outbreaks of disease with heavy loss of life on some early voyages. Although part of the British penal regime, ships were chartered - that is privately owned and commissioned for the journeys (Atkinson, 2005: 23). The captains and crews were not agents of the government and would often have their own priorities for the voyage. However, given that the purpose of convict voyages was not merely to remove unwanted individuals, but to supply a ready workforce for the development and population of new colonies, it was essential that prisoners arrived in 
good health. As such, on-board Surgeons were 'official representatives' of the government whose role was to 'see that the convicts were not mistreated or exploited by the captain or crew, as had happened on some early voyages, and to look after the prisoners' health during the long voyage' (Atkinson, 2005: 22-23).

Accordingly, a key strategy for ensuring a strong and well cargo of convicts was to 'order' them to time up on deck (see for example the diary of Surgeon and Superintendent George Thomson aboard the England ${ }^{4}$ ). The successful horizontal passage of individuals was therefore predicated on movements encompassing vertical dimensions. Power then, was projected through mobilities that were ordered, facilitated by the spatiality and volume of the ship itself. Indeed, John Duke, Surgeon aboard the ship Atlas bound from England to New South Wales in 1819, commented in his records the importance of allowing prisoners time on deck, the use of the wind-sails for ventilation in hot climes, and frequent bathing ${ }^{5}$. Likewise, Robert Espie, Superintendent and Surgeon during the voyage of the Dorothy 1820, remarked how 'the cleanliness enforced during the voyage helped keep the men healthy, as did exercising their minds in the school and allowing them access to the deck ${ }^{6}$.

However, the word 'enforced' used by Espie is indicative of the power relations embroiled in the movement of convicts on board. Indeed, such time on deck was rarely optional for convicts; rather it was a required mobility. Whilst some deck time was determined by weather (poor weather led to periods held below deck in order to shelter from the elements ${ }^{7}$ ), it was the Captain and Surgeon on board who literally held the keys for a vertical movement from below to up on deck. The movements between decks 
resulted in a vertical form of motion that not merely witnessed a physical upwards or downwards mobility of convicts between the levels of the ship, but likewise, represented the less tangible, hierarchical plays of power enacted between gaolers and prisoners; from the top, down. Through such disciplinary regimes, power pervaded the strata of space, piercing its lateral layers through the volume of the ship (to follow Elden, 2013). Espie's account from the Dorothy is illustrative of these manifold mobile realities and their significance aboard the convict ship.

Espie was a well-sailed Surgeon and Superintendent on the England to New South Wales route. He had already completed two stints in his capacity as MD aboard the Morely (1817) and the Shipley $(1819)^{8}$ and by the time he set sail on the Dorothy in 1820 he was highly experienced and his accounts reflected this. Less detailed than some other convict ship records, Espie rather spent time reflecting on the voyage and its successes. Unlike some surgeons, he appeared to have a strong sense of morality in view of protecting the safety and health of convicts (Atkinson, 2005). Nonetheless, even the measured and moral Robert Espie was part and parcel of a process whereby convict mobilities were decided by a higher power (literally and metaphorically) - a 'targeting' from above (Adey et al., 2011). Espie describes in his account how, during rough weather, the convicts were 'kept below' in the prison section of the ship. Whilst this was in some senses to protect them from the elements, the lower decks were the worst part of any ship. Lack of ventilation, leaks, over-crowding, and the extreme heat made stowage in the lower decks uncomfortable. Espie, along with the Captain would decide on when convicts would be allowed 'up'. This was often facilitated in 'divisions' 
breaking the convict cargo into groups and permitting them in small cohorts to move up to the deck and then around it ${ }^{9}$. Likewise, John Duke on the Atlas, reports how a routine mobility on board was the 'rotation' or 'churning' (Clear et al. 2003) of convicts from the prison to the deck:

12 June 1819 ... convicts on deck in rotation ... 13 June 1819 Prisoners rotated on deck 52 at a time ... 17-19 June; running down the channel, prisoners rotated on deck, no change to the sick list ... 20 June 1819 all prisoners on deck for 2 hours under armed guard while the prisons were thoroughly cleaned; 7-9 1819 July prisoners rotated on deck 40 at a time; 14 July 1819 prisoners not allowed on deck because of heavy rain; 17 July 1819 prisoners rotated and prisons cleaned as usual. (Diary of John Duke, Surgeon and Superintendent, Atlas, 12-17 June $1819^{10}$ )

Regularised movements up and down the levels of the ship were a 'usual' part of life on the convict ship and a way in which power permeated the three-dimensional structure, 'cutting through' the space (Weizman, 2003). These movements shaped incarcerated experience as convicts became accustomed to the motion of their bodies in accordance with the orders instructing them to the deck - to exercise, wash, air bedding, and pick oakum - and back down again.

As previously mentioned, vertical mobility upwards in the prison is often (but not always - see examples of using high-level cells for isolation) associated with good 
behaviour and reward. Conversely, as we have noted, the lower sections of the vessel were the most uncomfortable and unsanitary. As the surgeon of the Almorah noted, seasickness was acute in the lower part of the ship where the impact of the sea's motion was felt to a greater degree and where the movement of the vessel could not be observed (often remarked to be factor in alleviating motion sickness). Moreover, once under lock and key, the lower levels could also be a law unto themselves during the night. Superintendent and Surgeon William Rae noted how discipline was difficult to administer:

Repeat complaints having been made by Dennis Bird, Edward Grimstone and Thomas Pointon, three old men, that they were frequently harassed and injured in their persons, particularly after the prison was locked, by several young men dragging them about and otherwise maltreating them, the offenders however could never be detected until this morning. (Diary of William Rae, Surgeon and Superintendent, Eliza, 19 June-26 November $1822^{11}$ )

Due to these conditions, lower decks were used for reprimanding convicts. Prisoners who misbehaved would be moved below as punishment for their misdemeanours and the motion downwards represented the demise in their behaviour. This was where troublemakers were 'placed' who could not be trusted to be on deck (Cresswell, 1996). For example, on 6 October 1822 aboard the all-female convict ship John Bull, Mary Ryan and Mary Moran were found missing as the convicts were returned to the prison 
following exercise, air and work on deck. As William Elyard reported, 'Mary Ryan had been hidden away by Mr Weiss and Mary Moran by Moore the purser's steward' ${ }^{12}$. There is an implication here that both women had involved themselves in the commonly-practiced arrangement of acting as informal 'voyage-wives' for seamen, in exchange for a more comfortable life on higher decks (see Rees, 2003). Strictly speaking, this practice was prohibited. As such, the next day, he notes:

I performed the church service with all the convicts, passengers and children along with Mary Ryan and Mary Moran and read to them a religious tract on intemperance and another on chastity and endeavoured to point out to them the consequences that must result from them disobeying my orders against prostituting themselves to the seamen ... I consulted with the Captain ... and we determined to release them from Irons but to keep them below as prisoners till their arrival at Port Jackson. (Diary of William Elyard, Surgeon and Superintendent, John Bull, 7 October 1822) ${ }^{13}$

However, three days later for 'expressing contrition for their misconduct', the women were 'let on deck' ${ }^{14}$. This example demonstrates the use of vertical movements by gaolers for maintaining order and morality on the ship but also punishment where downwards, disciplinary movements of convicts represented punishment (and upwards movement a reward). This movement of prisoners vertically between decks as a method of control, order and punishment was exemplified in the worst cases of bad behaviour 
when convicts were sentenced to time in the lowest, most cramped section of the ship the coal hole.

Some two years following his stint in charge of the Dorothy, Robert Espie was once more at the helm of a convict voyage, this time travelling between August 1822 and March 1823 from Woolwich to Van Diemen's Land (Tasmania) and New South Wales on the Lord Sidmouth (see Atkinson, 2005). The cargo consisted of 97 female convicts, along with a further 23 children and 21 'free' passengers making their way to the Australian Colonies (some to meet their husbands on arrival ${ }^{15}$ ). Similar to Elyard's accounts, Espie's records reveal a troublesome voyage. Numerous convicts were confined to the 'coal hole' for bad behaviour. For example on 9 January 1823, Espie 'punished Elizabeth Capps, a prisoner from Newgate, with confinement in the coal hole all day for violent and abusive language' and on 22 January, Sarah Phillips and Ann Gill were also sent there for 'riotous behaviour' ${ }^{16}$. Just one day later,

Lat $39^{\circ} 17^{\prime \prime} \mathrm{S}$, Long $88^{\circ} 21^{\prime \prime} \mathrm{E}$ Weather mild and considerably more moderate ... confined Sarah Phillips and Ann Gill in the Coal Hole again for having said last night after I released them they did not value me, with many their hard words of indecorous meaning - at 2 o'clock served a gill of wine to each of the [prisoners] except two above mentioned and two others. (Diary of Robert Espie, Surgeon and Superintendent, Lord Sidmouth, 23 January $1823^{17}$ ) 
Removal to the coal hole was merely one of a myriad of punishments (others included the shaving of women's heads; handcuffing; handcuffing prisoners together and flogging). It was a particular form of punishment and a particular form of mobility enacted and enforced on board that reminded prisoners of their lower status. Furthermore, whilst such disciplinary, vertical mobilities were part and parcel of life on board, they were crucial to the success of the journey of any voyage; and the deliverance of a ship-full of ordered, disciplined and healthy individuals ready to populate the colonies. As such, these vertical micro-mobilities reveal themselves as being vital to, and in simultaneous juxtaposition with, the wider macro-scale, horizontal purpose of the voyage.

Indeed, the regimes of power wrought through the volumes of the ship - a confined, limited space at sea - were connected to the macro operation of colonial politics at time (for example, the subjugation of certain subjects in hierarchies of control and the brutal process of disciplining behaviour through (im)mobilising practices). Marcus Rediker (2007) has noted that the slave ship was a microcosm of the larger processes of terror and violence that came to characterise the Atlantic trade in human life. Likewise, the prison ship came to encapsulate sovereign modes of control that were extended at the macro scale across the colony (see also Benton 2010). These were modes of control that stretched across space but were founded upon a vertical ontology of discipline on board ships achieved through hierarchy, confinement and three-dimensional spatial organisation. 
Yet vertical movements and the use of volume, were also a way in which prisoners fought back against their confinement. Indeed, whilst prisoners were ordered (and at times permitted of their will) to the open deck, all convicts were, for the most part, forced to return to the prison at night. The prison, below deck, was where the rumbles of mutiny would on occasion occur. To enact any kind of mutiny required convicts to literally and figuratively 'rise' up and take 'over' the ship. On board the Richmond, Superintendent Wilson reported on a suspected mutiny:

I was informed by the sentry that [a] very improper conversation had taken place at the fore hatchway amongst some of the prisoners last night. He immediately called out to Everett the boatswain and pointed out to him the berth from whence it proceeded. I examined into it and found one of the prisoners had said that the first favourable opportunity which offered they would all rise and throw every soul overboard, I was informed by several of the guard that they heard much similar conversation lately amongst the prisoners since the $5^{\text {th }} \ldots$ (Diary of $\mathrm{T}$ B Wilson, Surgeon and Superintendent, The Richmond, 9 December $1821^{18}$ )

Much like the metaphoric and literal significance of confining prisoners on the lower levels of the ship and in the coal hole, there was a significance to prisoners 'rising up' in reaction to the authorities. These were attempts to subvert the plays of power through a coalescing of vertical and horizontal movements on the ship - pushing up the levels of the deck in order to take control and also pushing forwards, against the doors of the 
prison in order to break free. As Hugh Walker, Surgeon of the Guildford in 1820 (with almost 190 prisoners on board) noted on 7 June, the 'alarm (was) given at 2:30am that convicts were forcing the fore part of the prison, (but) all was found to be quiet below decks but a plank separating the hospital from the prison had been forced. Convicts and their beds searched and their irons examined ${ }^{19}$.

In all the accounts we read, we found no instances of mutiny whereby convicts took control of the vessel. Yet, these attempts to resist (to mutiny) should not be overlooked. These mobilities - the rising up and pushing forward of the convict - were significant in that they were mobilities of the body that contested its disciplined, routinised movements normally enacted on the ship. However unsuccessful, such movements reproduced the status of the convict as lower and inferior, but also produced the subject as having some limited power in the face of the authorities. As we have noted elsewhere (Peters and Turner, 2015), convict bodies are not simply passive in relation to dominant, confining power - mobilities are enacted that challenge and reform, or simply make known those regimes of power that discipline, order and control.

That said, there were occasions where convicts did escape the irons, shackles and limited space of their confinement below deck, and the ordered, regularised and disciplined time on deck. During the 1818 voyage of the Earl St Vincent, convict William Keating 'plunged overboard'. It was reported he was found 'holding the bobstay' (the strong ropes used to hold down the bowsprit of a ship and keep it steady). On his discovery in this precarious position, 'the alarm was given' but it was too late. In 
spite of 'every exertion made to recover him', it was 'to no effect' ${ }^{20}$. Keating had made the ultimate escape through a vertical mobility - jumping overboard. Although resulting in the death of the convict, such actions were a method of freedom and emancipation from their fate aboard and later in the Colony.

Therefore, mobilities on board the convict ship were, by and large, as Moran et al. (2012) would contend, coerced, determined and decided by those with a dominant and dominating power over the convicts - the Surgeons, Captains and even the crews of seamen. Yet, power was also held by the convicts (see Sharpe et al., 2000) who, through acts of resistance, would use vertical mobilities to challenge regimes of disciplinary control during voyages to the Colonies. Such mobilities threatened the ability of the Captain and Surgeon to transport an unruly, immoral lot from point A, as a reformed, routinised and sanitary group to point $\mathrm{B}$, thus reiterating the complex interaction between those vertical mobilities on board the ship and its wider horizontal movements.

\section{Beyond horizontal: taking seriously verticality in carceral space}

In this paper we have built upon the important work of Moran et al. (2012) and others (e.g. Pickering and Weber 2006) in mobilising incarceration. We have done so through arguing that the vertical dimensions of prison space should be taken seriously in regimes of discipline and practices of resistance. To make this claim we have considered the historical case of the convict ship - a space which is an exemplar for investigation given its limited geographical parameters (which necessities upwards and downwards movements) in situ with its horizontal movement across a more or less 
boundless sea. Accordingly, whilst recent work has taken steps to unlock carceral studies from their fixed frames of understanding, this effort, as we have contended, could be productively extended. The convict ship helps us to do this. Indeed, Moran et al. (2012) set an agenda for an examination of carceral space that takes mobility seriously. Yet, as we have argued, there is much work to do to bring mobilities-thinking fully into the carceral realm. One critique we have waged is with the relatively straightforward way mobility is understood - as the wholesale movement of the detained subject from place to place (the site of 'holding' to the prison, or between prisons). This interpretation of mobilities, as predicated on literal and lateral movements between points $\mathrm{A}$ to $\mathrm{B}$, or in a loop, offers only a partial insight in the manifold mobilities that are encapsulated in incarcerated life.

The horizontal journey is in some respects an enduring feature of any mobility in life as we travel a path or line. Yet studies of mobility urge us to pay attention to what occurs in-between, during movement. It is these that require our attention as they fundamentally shape what it is, means and feels to move or not move and it is these that carceral scholars have yet to fully reveal. We posit that it is vital to do so. We argue that a vertical dimension, so thoroughly embedded within carceral architectures, policies and experiences, is one-step towards better grasping how mobility shapes and is shaped by processes of confinement, detainment and imprisonment.

Accordingly, here, focusing on the convict ship, we have demonstrated how mobilities occur on deck, down below and overboard - moving beyond horizontal mobilities of prisoner transportation. Indeed, as we have illustrated, there are a 
multitude of vertical movements that are part of incarcerated experience. Power occurs through the many layers of space that rise up perpendicularly (following Weizman, 2003). Prisoners were moved up and down between decks; they are also rotated, and all as a matter of routine and the ordered regulation of the body, but also as a method of punishment and reprimand. Prisoners likewise engage with vertical and horizontal movements together to resist the regimes of power that so often oppressed them from above, to confines below deck (rising up, pushing forwards). The convict ship provides an exemplary case study of vertical mobility in carceral settings, because ships, facilitating horizontal movement, are also, in addition, sites of upwards and downwards movements, rotational movement and micro movements - in view of the motion of the ship itself in and also the movement of its cargo on board.

Through this account of the convict ship, we have sought to show how carceral scholars may extend their focus on mobility. Indeed, taking into account the vertical movements that occur in carceral settings adds 'height and depth' to discussions, demonstrating 'the possibilities of relative location (in) affording additional means of control' (Bridge, 2013: 55). Indeed, on the convict ship; moving prisoners up and down was a method of securing order on the ship and, conversely, contesting that control. However, there remains a greater need to fully mobilise accounts of incarcerated life beyond this example. This is not merely for developing a theoretical 'depth' to discussions, but to aiding the practical work of understanding the realities of incarceration and to the job of planning and designing prison space and to the performed methods of control and security and that are necessary in prisons in an age of 
punitiveness. Vertical movements are crucial considerations when specifically noting the need to restrict horizontal movements in landed prison space. For example, in Britain and the USA's hyper-carcerative regimes, higher prison walls now contribute implicitly to the securisation of carceral spaces. This in conjunction with 'heightened' surveillance and 'deeper' boundaries nods towards an environment where immobility is co-constituted (and therefore predicated upon) the recognition of possible vertical and horizontal movements.

\section{References}

Adey P (2009) Mobility. London: Routledge.

Adey P (2010) Vertical security in the megacity legibility, mobility and aerial politics. Theory Culture \& Society 27 (6): 51-67.

Adey P, Whitehead M and Williams AJ (2011) Introduction: Air-target distance, reach and the politics of verticality. Theory Culture \& Society 28(7-8): 173-187.

Anderson C (2000) Convicts in the Indian Ocean: Transportation from South Asia to Mauritius, 1815-53. New York, NY: St. Martin's Press.

Anim-Addo A (2014) 'The great event of the fortnight': Steamship rhythms and colonial communication. Mobilities 9(3): 369-383.

Atkinson J (2005) Mary Proctor: Convict, Pioneer and Settler. Kenthurst: Rosenberg Publishing.

Bateson C (2004) The Convict Ships, 1787-1868. Glasgow: Brown, Son and Ferguson. 
Benton L (2010) A Search for Sovereignty: Law and Geography in European Empires, 1400-1900. Cambridge: Cambridge University Press.

Bozovic M (1995) (ed) The Panopticon Writings. London: Verso.

Bridge G (2013) Territory, now in 3D! Political Geography 34: 55-57

Brooke A and Brandon D (2005) Bound For Botany Bay: British Convict Voyages to Australia. London: National Archives.

Campbell CF (1994) The Intolerable Hulks: British Shipboard Confinement, 17761857. Cirencester: Heritage Books.

Clear TR, Rose DR, Waring E and Scully K (2003) Coercive mobility and crime: A preliminary examination of concetrated incarceration and social disorganisation. Justice Quaterley 20: 33-64.

Conlon D (2011) Waiting: Feminist perspectives on the spacings/timings of migrant (im)mobility. Gender, Place and Culture 18(3): 353-360

Cresswell T (1996) In Place/Out of Place: Geography, Ideology, and Transgression. Minneapolis, MN: University of Minnesota Press.

Cresswell T (2010) Towards a politics of mobility. Environment and Planning D: Society and Space 28(1): 17-31.

Cresswell T and Merriman P (2012) Introduction. In: Cresswell, T and Merriman, P (eds) Geographies of Mobilities: Practices, Spaces, Subjects. Farnham: Ashgate, pp. $1-15$.

Elden S (2013) Secure the volume: Vertical geopolitics and the depth of power. Political Geography 34: 35-51. 
Gill N (2009) Governmental mobility: The power effects of the movement of detained asylum seekers around Britain's detention estate. Political Geography 28: 186196.

Hasty W and Peters K (2012) The ship in geography and the geographies of ships. Geography Compass 6(11): 660-676.

The Howard League for Penal Reform (2012) History of the Prison System. Available at: http://www.howardleague.org/history-of-prison-system/ (accessed 12 October 2012).

Ingold T (2007) Lines: A Brief History. Abingdon: Routledge.

Leary J (2014) (ed) Past Mobilities. Farnham: Ashgate.

Loyd JM, Mitchelson M and Burridge A (2012) Beyond Walls and Cages: Prisons, Borders, and Global Crisis. Athens, GA: University of Georgia Press.

Martin LL and Mitchelson ML (2009) Geographies of detention and imprisonment: Interrogating spatial practices of confinement, discipline, law, and state power. Geography Compass 3(1): 459-477.

Merriman P (2007) Driving Spaces: A cultural-historical geography of England's M1 motorway. Oxford: Blackwell-Wiley.

Merriman P (2013) Mobility, Space and Culture. London: Routledge.

Moran D (2015) Carceral Geography: Spaces and Practices of Incarceration. Farnham: Ashgate. 
Moran D, Piacentini L and Pallot J (2012) Disciplined mobility and carceral geography: Prisoner transport in Russia. Transactions of the Institute of British Geographers 37(3): 446-460.

Ong CE, Minca C and Felder M (2014) Disciplined mobility and the emotional subject in Royal Dutch Lloyd's early twentieth century passenger shipping network. Antipode 46(5): 1323-1345.

Pallot J (2005) Russia's penal peripheries: Space, place and penalty in Soviet and postSoviet Russia. Transactions of the Institute of British Geographers 30(1): 98112.

Pallot J (2007) 'Gde muzh, tam zhena' (where the husband is, so is the wife): Space and gender in post-Soviet patterns of penality. Environment and Planning A 39(3): $570-589$.

Peters K and Turner J (2015) Between crime and colony: interrogating (im) mobilities aboard the convict ship. Social and Cultural Geography 16(7): 844-862.

Pickering S (2014) Floating carceral spaces: Border enforcement and gender on the high seas. Punishment \& Society 16(2): 187-205.

Pickering S and Weber L (2006) (eds) Borders, Mobility and Technologies of Control. Netherlands: Springer.

Radzinowicz L and Hood R (1986) A History of English Criminal Law and its Administration from 1750. Vol.5, The Emergence of Penal Policy. London: Stevens and Sons Ltd.

Rediker M (2007) The Slave Ship: A Human History. London: Verso. 
Rees S (2003) The Floating Brothel: The Extraordinary True Story of an Eighteenth-

Century Ship and its Cargo of Female Convicts. New York, NY: Hyperion.

Sharpe JP, Routledge P, Philo C and Paddison R (2000) Entanglements of Power:

Geographies of Dominance/Resistance. London: Routledge.

Sheller M and Urry J (2006) The new mobilities paradigm. Environment and Planning A 38(2): 207-226.

Steinberg P (2001) The Social Construction of the Ocean. Cambridge: Cambridge University Press.

Steinberg P and Peters K (2015). Wet ontologies, fluid spaces: giving depth to volume through oceanic thinking. Environment and Planning D: Society and Space 33(2): 247-264.

Turner J (2012) Criminals with 'community spirit': Practising citizenship in the hidden world of the prison. Space and Polity 16(3): 321-334.

Turner J (2013a) Disciplinary engagements with prisons, prisoners and the penal system. Geography Compass 7(1): 35-45.

Turner J (2013b) Re-'homing' the ex-offender: Constructing a 'prisoner dyspora'. Area 45(4): 485-492.

Turner J (2014) 'No place like home': Boundary traffic through the prison gate. In: Jones R and Johnson C (eds) Placing the Border in Everyday Life. Farnham: Ashgate, pp. 227-250. 
Turner J (2016) The Prison Boundary: Between Society and Carceral Space. London: Palgrave Macmillan.

Urry J (2007) Mobilities. London: Polity.

Van Hoven B and Sibley D (2008) 'Just duck': The role of vision in the production of prison spaces. Environment and Planning D: Society and Space 26(6): 10011017.

Vaughan B (2000) The civilizing process and the Janus-face of modern punishment. Theoretical Criminology 4(1): 71-91.

Vaver A (2011) Bound With an Iron Chain: The Untold Story of How the British Transported 50,000 convicts to Colonial America. Westborough, MA: Pickpocket Publishing.

Weizman E (2003) The politics of verticality. Available at: http://www.opendemocracy.net/ecology-politicsverticality/article_801.jsp (accessed 13 June 2014).

Wener R (2012) The Environmental Psychology of Prisons and Jails: Creating Humane Spaces in Secure Settings.Cambridge, MA: Cambridge University Press.

Willis J (2008) Punishment and the cultural limits to state power in late 18th-century Britain. Punishment \& Society 10(4): 401-428.

\footnotetext{
${ }^{1}$ National Archives ADM 101/19/8/4

${ }^{2}$ National Archives ADM 101/24/1

${ }^{3}$ National Archives ADM 101/38/1/8
} 
${ }^{4}$ National Archives ADM 101/26/1/3

${ }^{5}$ National Archives ADM 101/6/2/3

${ }^{6}$ National Archives ADM 101/19/8/4

${ }^{7}$ National Archives ADM 101/19/8/4

${ }^{8}$ Espie went on to complete further voyages between England and Australia and Van Diemen's Land (Tasmania).

${ }^{9}$ National Archives ADM 101/19/8/4

${ }^{10}$ National Archives ADM 101/6/2/1

${ }^{11}$ National Archives ADM 101/23/3/2

${ }^{12}$ National Archives ADM 101/38/7/4

${ }^{13}$ National Archives ADM 101/38/7/4

${ }^{14}$ National Archives ADM 101/38/7/4

${ }^{15}$ As reported in Folio 32, National Archives ADM 101/44/10/3

${ }^{16}$ As noted in Folio 29, ADM 101/44/10/3

${ }^{17}$ National Archives ADM 101/44/10/3

${ }^{18}$ National Archives ADM 101/64/2/3

${ }^{19}$ National Archives ADM 101/31/2/1

${ }^{20}$ National Archives ADM 101/21/7A/1 